
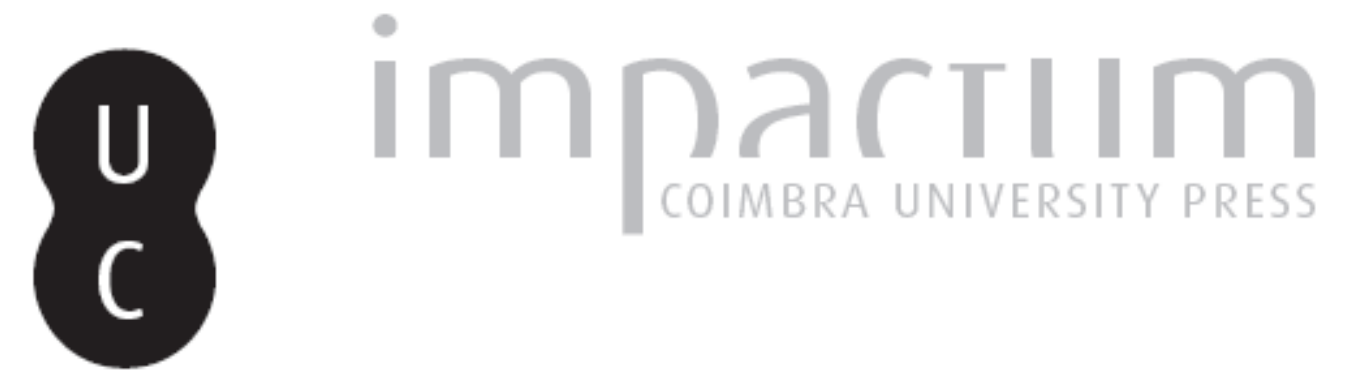

\title{
El mal, el pecado y el castigo en el antiguo egipto
}

\section{Autor(es): $\quad$ Padró, Josep}

Publicado por: Centro de História da Universidade de Lisboa

URL persistente:

URI:http://hdl.handle.net/10316.2/23712

DOI:

DOI:http://dx.doi.org/10.14195/0871-9527_20_1

Accessed : $\quad$ 26-Apr-2023 08:20:31

A navegação consulta e descarregamento dos títulos inseridos nas Bibliotecas Digitais UC Digitalis, UC Pombalina e UC Impactum, pressupõem a aceitação plena e sem reservas dos Termos e Condições de Uso destas Bibliotecas Digitais, disponíveis em https://digitalis.uc.pt/pt-pt/termos.

Conforme exposto nos referidos Termos e Condições de Uso, o descarregamento de títulos de acesso restrito requer uma licença válida de autorização devendo o utilizador aceder ao(s) documento(s) a partir de um endereço de IP da instituição detentora da supramencionada licença.

Ao utilizador é apenas permitido o descarregamento para uso pessoal, pelo que o emprego do(s) título(s) descarregado(s) para outro fim, designadamente comercial, carece de autorização do respetivo autor ou editor da obra.

Na medida em que todas as obras da UC Digitalis se encontram protegidas pelo Código do Direito de Autor e Direitos Conexos e demais legislação aplicável, toda a cópia, parcial ou total, deste documento, nos casos em que é legalmente admitida, deverá conter ou fazer-se acompanhar por este aviso.

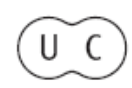




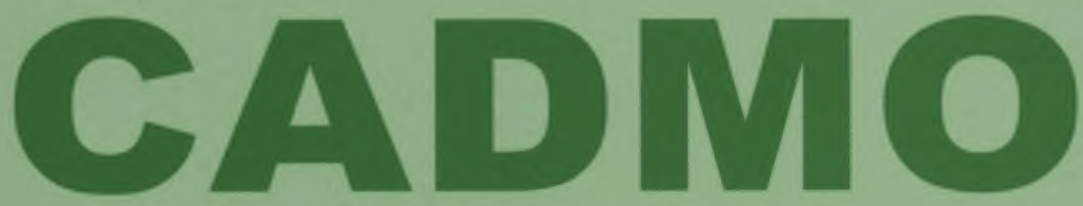

Revista de História Antiga

\author{
Centro de História \\ da Universidade de Lisboa
}

\title{
20
}

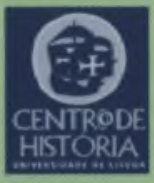

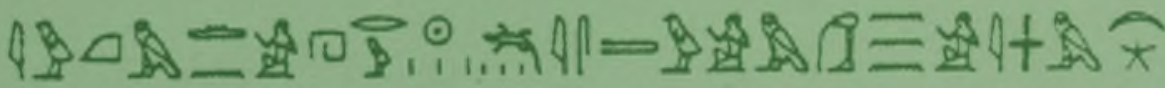

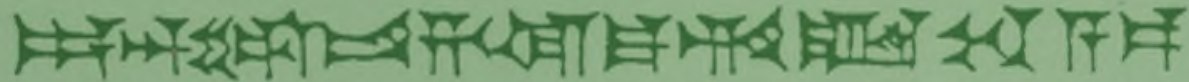

MHNIN AEI $\Delta$ E $\Theta E A ~ \Pi H \Lambda H I A \triangle E \Omega$ 


\section{EL MAL, EL PECADO Y EL CASTIGO EN EL ANTIGUO EGIPTO}

JOSEP PADRÓ

Universidade de Barcelona

jpadro@ub.edu

\section{Presentación}

El presente trabajo es el resultado final, por lo que respecta a Egipto, de un proyecto promovido inicialmente por la sección de la Universidad de Salamanca del Instituto del Próximo Oriente Antiguo (IPOA), y presentado en marzo del 2000 en dicha Universidad. Dicho proyecto interdisciplinario llevaba por título «La sombra de Dios. El mal, la culpa y el pecado en las culturas orientales", y tenía como objetivo plantear el llamado "problema del mal» en el conjunto de las civilizaciones orientales, desde Egipto hasta el Japón. Lamentablemente, y por problemas ajenos tanto a la organización como a los diversos autores, el proyecto no llegó a feliz término y se interrumpió antes de su culminación.

Por ello, y ante la invitación del Prof. Luís M. de Araújo de participar en el volumen especial n. $\stackrel{2}{20}$ de la revista Cadmo de la Universidad de Lisboa, he creído que sería buena idea desempolvar dicho proyecto y ponerlo al día en lo referente a Egipto, ya que la idea y su planteamiento siguen pareciéndome válidos.

$\mathrm{He}$ de señalar, con todo, algunos de los condicionantes del proyecto inicial, que explican el formato final de presentación de este trabajo. La organización pidió a los colaboradores que aportasen abundantes textos justificativos de sus asertos, que permitieran además comparar la respuesta al "problema" de cada una de las civiliza- 
ciones estudiadas. Ésta es la explicación de la abundancia de textos traducidos que aporto, y que en todo caso he juzgado oportuno mantener para ahorrar al lector de este trabajo la consulta de la bibliografía donde se da la edición de dichos textos. Se trata, pues, de una pequeña antología de textos seleccionada sobre la cuestión lo que ofrecemos aquí. La bibliografía está, de todos modos, referenciada, y siempre será útil tener agrupados los principales textos referidos al problema del mal en Egipto, juntos en un solo lugar.

\section{Introducción}

Antes de entrar en materia es preciso, como planteamiento previo, recordar que el Egipto faraónico fue el estado más humano e incruento dentro del Mediterráneo antiguo. Ello no significa, desde luego, que allí no pudiesen cometerse barbaridades o injusticias; pero sí significa que aquella antigua civilización sale beneficiada si la comparamos con sus vecinas, tanto en el espacio como en el tiempo, hasta el extremo de poder dar valor absoluto a nuestras primeras aseveraciones. De un modo más concreto, también podemos afirmar que Egipto fue el primer estado territorial centralizado de la historia, en el que el concepto de simple explotación de tierras y gentes fue bien pronto sustituido por el concepto de administración.

Ya que la civilización egipcia duró varios milenios nos ha sido forzoso no sólo resumir, sino sobre todo elegir. Para una mayor claridad expositiva creemos necesario empezar por hacer un repaso del planteamiento que hemos dado a nuestro tema. Empezaremos explicando cuáles son las fuentes para el estudio de la religión egipcia. Seguiremos por exponer los orígenes de la misma, con el impacto que en ella han dejado tanto la mitología como la teología. A continuación veremos la personificación del mal en el panteón egipcio: nos referimos al dios Set. Seguiremos con la consideración del mal y el pecado en el pensamiento religioso egipcio. $Y$ terminaremos con algunas reflexiones sobre el castigo.

Como ha dejado dicho un egiptólogo, si del mundo clásico greco-romano lo que nos queda es un edificio arruinado, del Egipto faraónico sólo quedan flotando los restos de un naufragio. Con este símil lo que quiere significarse es que lo acontecido con la civilización egipcia fue un auténtico naufragio que acarreó la interrupción total de su conocimiento y de su estudio y comprensión. En consecuencia, en la 
conservación de sus documentos no ha intervenido en absoluto algún tipo de selección, sino simplemente el azar.

En lo referente a la religión, son escasos los textos seguidos que han llegado hasta nosotros: los Textos de las Pirámides del Imperio Antiguo, los Textos de los Sarcófagos del Imperio Medio, el Libro de los Muertos, el Libro de lo que hay en el Más Allá, y algún texto funerario más. Los textos narrativos mitológicos son todavía más escasos, lo que hace muchas veces difícil la sistematización de nuestros conocimientos.

Los dioses egipcios han podido ser clasificados en diferentes categorías: la más numerosa es la de los dioses locales, como Horus en Behudit del Norte, Neit en Sais, Atum en Heliópolis, Tot en Hermópolis Parva, Ptah en Menfis, Set en Ombos o Amón en Tebas; también hay dioses agrarios como Osiris; dioses geográficos como Hapy (el Nilo); dioses familiares; dioses extranjeros; hombres y reyes divinizados; dioses creados por la especulación teológica, como Maat; y aún el rey, dios en tanto que rey ${ }^{(1)}$.

Los textos más antiguos que han llegado hasta nosotros datan del Imperio Antiguo; sin embargo, hay que tener en cuenta que los Textos de las Pirámides, aunque inscritos en los muros de las pirámides a partir del final de la dinastía $\mathrm{V}$, son en realidad muy arcaicos, datando su composición de tiempos prehistóricos. De esta manera, los Textos de las Pirámides nos permiten estudiar la evolución del pensamiento religioso egipcio a lo largo del Período Predinástico.

Así, podemos establecer que originariamente cada nomo o provincia tenía su dios local, que podía ser masculino o femenino, y que a pesar de tratarse ya de dioses con figura humana, conservaban trazas evidentes de una zoolatría anterior. El sumo sacerdote de estos dioses locales era al mismo tiempo el príncipe hereditario que gobernaba su nomo. A partir de este momento, los avatares político-sociales que acontecieron en el Egipto predinástico fueron directamente responsables de la evolución posterior ${ }^{(2)}$. De este modo, a cada dios local pronto se le asoció su paredro de sexo contrario, así como un dios-niño, hijo de ambos; sin embargo, estas tríadas divinas fueron relativamente inestables, y esta inestabilidad se mantuvo en algunos casos hasta la Baja Época. Las únicas excepciones en la formación de tríadas fueron Atum de Heliópolis y Neit de Sais, que no tuvieron jamás paredro.

Ulteriormente, las elucubraciones de las distintas escuelas teológicas que fueron surgiendo especialmente en el Bajo Egipto, permi- 
tieron poner orden en el panteón. La influencia de sus especulaciones llegó a traspasar en ocasiones fronteras espaciales y temporales, hasta alcanzar en algún caso los tiempos modernos. El clero de Heliópolis fue el primero en organizar el panteón egipcio, evidentemente en provecho propio: convirtiendo a su dios local Atum en el dios primordial, ellos se convertían a su vez en árbitros de las relaciones entre nomos, mucho antes de que se produjese la unificación política de Egipto. Según este sistema, Atum tuvo por masturbación dos hijos: Shu (el dios-aire) y Tfenis (la diosa-agua), quienes a su vez engendraron a Gueb (el dios-tierra) y a Nut (la diosa-cielo). Así se instauraba un panteísmo que justificaba la jurisdicción sacerdotal sobre los asuntos terrenales. Pero hay que reconocer que la elaboración de este sistema fue llevada a cabo no sólo por razones interesadas: detrás de él puede percibirse un esfuerzo real por comprender y por explicar el cosmos con coherencia.

\section{La noción de mal y de pecado}

Paralelamente, los primeros intentos políticos y militares de unificación tanto del Delta como del Egipto entero llevaron a los sacerdotes de Heliópolis a pactar con el poder temporal constituido, introduciendo como consecuencia de ello y en tanto que hijos de Gueb i Nut a los personajes de la leyenda osiríaca, antepasados del rey y forjadores míticos de la monarquía faraónica: Osiris, Isis, Set y Neftis. Quedaba constituida de este modo la Gran Enéada de Heliópolis.

Pero el mito de Osiris e Isis sólo está narrado entero por Plutarco. Sabemos que algunos de sus episodios eran escenificados, especialmente en Abido con motivo de la celebración de los misterios de Osiris. Sin embargo, los textos egipcios al respecto son siempre muy parciales, y muchas veces proceden sólo por alusiones. De modo que, dado su interés para el objetivo que nos ocupa, pues en este mito es donde se nos presenta al dios Set, vamos a recoger a continuación los pasajes más significativos del relato de Plutarco ${ }^{(3)}$ :

12. Se cuenta este mito con el menor número de palabras posible, omitiendo lo que es completamente inútil y superfluo. Dicen que el Sol(4), habiéndose enterado de la unión secreta de Rea con Crono ${ }^{(5)}$, lanzó contra ella la maldición de que no daría a luz ni en el curso del mes ni del año; pero que Hermes ${ }^{(6)}$, enamorado de la diosa cohabitó 
con ella; después, habiendo jugado a las damas con Selene y habiendo ganado de cada uno de sus períodos luminosos la setentava parte, formó con todo cinco días y los añadió a los trescientos sesenta; a éstos ahora los egipcios los llaman "adicionales" y en ellos celebran los nacimientos de los dioses. Dicen que en el primero nació Osiris y que cuando nació surgió una voz que decía: "el señor de todo llega a la luz". Y algunos dicen que un tal Pamiles, que estaba sacando agua en Tebas, oyó una voz que salía del templo de Zeus ${ }^{(7)}$ y le ordenaba proclamar a gritos que el gran rey benefactor Osiris había nacido, y que por esto crió a Osiris, por habérselo confiado Crono, y que en su honor se celebra la fiesta de las Pamilias semejante a las Faleforias. En el segundo día nació Arueris ${ }^{(8)}$, al que llaman Apolo y algunos Horus el Viejo, y en el tercero Tifón ${ }^{(9)}$, no a su tiempo ni por la vía normal, sino que saltó del costado de su madre, habiéndolo desgarrado de un golpe. En el cuarto día nació Isis, en regiones completamente húmedas, y en el quinto Neftis, a quien llaman también Teleuté y Afrodita y algunos incluso Níke. Dicen que Osiris y Arueris son hijos del Sol, Isis de Hermes, y Tifón y Neftis de Crono. Por esta razón también, al tercero de los días adicionales los reyes lo consideraban nefasto y no se ocupaban de los asuntos públicos ni cuidaban de su persona hasta la noche. Dicen que Neftis se casó con Tifón y que Isis y Osiris, enamorándose incluso antes de nacer, se unieron en la oscuridad del seno materno. $Y$ algunos dicen también que de este modo nació Arueris y que es llamado "Horus el Viejo" por los egipcios, pero Apolo por los griegos.

13. Tan pronto como Osiris fue rey de los egipcios, los liberó de una vida indigente y salvaje, mostrándoles los frutos, promulgando leyes y enseñándoles a honrar a los dioses; después recorrió toda la tierra civilizándola sin la más mínima necesidad de armas, sino arrastrando a la mayoría con el hechizo de la persuasión y de la palabra, acompañadas de todo tipo de canto y de música; razón por la que los griegos creen que es el mismo dios que Dioniso. En su ausencia, Tifón no osó emprender ninguna acción porque Isis vigilaba muy de cerca y estaba alerta con firmeza, pero, cuando volvió, maquinó contra él un engaño tras haber formado un grupo de setenta y dos conspiradores y teniendo como cómplice a una reina procedente de Etiopía, a la que llaman Aso. Habiendo medido ocultamente el cuerpo de Osiris y habiendo hecho fabricar un arca hermosa y extraordinariamente adornada, de su tamaño, la hizo llevar a un banquete. Deleitados y admirados todos ante su vista, Tifón, bromeando, prometió regaiar el arca a aquél que, tendido dentro, fuera del mismo largo. Intentándolo todos, uno a uno, como nadie encajaba, se metió Osiris y se tendió completamente. Los conjurados se precipitaron a poner la tapa y, habiéndola sujetado con clavos desde fuera, sobre los que 
derramaron plomo fundido, transportaron el arca hasta el río y la dejaron ir a través de la boca Tanítica hacia el mar, boca a la que, a causa de esto, incluso ahora los egipcios la llaman todavía "la odiosa" y "la abominable". Dicen que esto ocurrió en el decimoséptimo día del mes Athyr, en el que el sol pasa por el Escorpión, en el vigésimo octavo año del reinado de Osiris. Algunos, sin embargo, dicen que son sus años de vida, no que haya reinado tanto tiempo.

14. Por ser los Panes y los Sátiros los primeros que, al habitar la región que circunda a Quemis, se enteraron del acontecimiento y dieron la noticia de lo que había ocurrido, los repentinos tumultos y consternaciones de la multitud todavía ahora a causa de esto son llamados "pánicos"; e Isis, al enterarse, se cortó enseguida una de sus trenzas y se puso un vestido de luto, allí donde está la ciudad que todavía ahora lleva el nombre de Copto. Otros piensan que el nombre significa "privación", pues la idea de "privar" la expresan con kóptein. Errante por todas partes y sin salida, a nadie a quien se acercaba dejaba de interrogar, sino que incluso a unos chiquillos con los que se encontró les preguntó por el arca; se dio la circunstancia de que ellos la habian visto y señalaron la boca a través de la cual los amigos de Tifón dejaron ir el ataúd al mar. Por esta razón piensan los egipcios que los niños tienen poder mántico y sobre todo obtienen augurios de las palabras de los niños cuando juegan en los templos y gritan lo que les viene a la cabeza.

Isis, tras enterarse de que Osiris, enamorado, se había unido con su hermana por ignorancia creyendo que era ella, y habiendo visto como prueba la corona de meliloto que aquél dejó a la puerta de Neftis, buscaba al niño (pues tan pronto como ésta dio a luz lo expuso por temor a Tifón); encontrado con dificultad y esfuerzo bajo la guía de los perros, Isis lo crió, y él se convirtió en su guardián y servidor y recibió el nombre de Anubis, y se dice que protege a los dioses, como los perros a los hombres.

15. Después de esto se enteró de que el arca, habiendo sido empujada por el mar hasta el territorio de Biblos, las olas la pusieron dulcemente en los brazos de una mata de erica; la mata, convirtiéndose en poco tiempo en un hermosísimo y crecido tronco la envolvió, se desarrolló en derredor y la ocultó dentro de sí; el rey, admirado del tamaño de la planta y habiendo hecho cortar el tronco que contenía el ataúd, sin que se viera, lo utilizó como soporte del techo de su palacio. Y dicen que Isis, habiéndose enterado de esto por un rumor de inspiración divina, llegó a Biblos y, sentada sobre una fuente en actitud apenada y llorosa, no intercambiaba palabra con ninguna otra persona, pero acogía afectuosamente a las criadas de la reina y les mostraba sentimientos de amistad trenzando sus cabellos e impregnándoles el cuerpo de la admirable fragancia que emanaba del suyo. Al ver la reina 
a las criadas le sobrevino el deseo de la extranjera, de sus cabellos y de su piel, que exhaiaba ambrosía; y así, habiendo sido llamada y convirtiéndose en su amiga íntima, aquélla la hizo nodriza de su hijito. El nombre del rey dicen que era Malcandro; el de la reina, unos que Astarte, otros Saosis y otros Némano, que los griegos dirían Atenaíde. 16. Isis criaba al niño poniendo el dedo en su boca en lugar del pecho, y por la noche quemaba las partes mortales de su cuerpo; y ella, convertida en golondrina, volaba alrededor de la columna y gemía, hasta que la reina, que estaba vigilando y que lanzó un grito cuando vio a la criatura envuelta en llamas, la privó de la inmortalidad. La diosa se reveló y pidió la columna que sostenía el techo; tras haberla removido con toda facilidad, cortó la capa de erica, después la cubrió con tela de lino, la bañó en mirra y se la confió a los reyes, y todavía ahora los de Biblos veneran el leño depositado en el templo de Isis. Cayó sobre el ataúd y lanzó un lamento tal que el más joven de los dos hijos del rey murió; retuvo al mayor con ella y habiendo colocado el ataúd en una barca zarpó. Y, cuando el río Fedro alimentó un viento bastante violento hacia el amanecer, encolerizada secó la corriente.

[...]

18. Isis se encaminó junto a su hijo Horus, que estaba siendo criado en Buto, y puso el ataúd en un lugar apartado. Tifón, que cazaba por la noche a la luz de la luna, tropezó con él, y al reconocer el cuerpo, lo dividió en catorce trozos y los dispersó. Isis, al saberlo, lo buscaba navegando a través de las marismas en un bote de papiro; ésta es la razón por la que quienes navegan en botes de papiro no son atacados por los cocodrilos, que muestran ya sea su temor ya su veneración hacia la diosa. Por esto también se dice que hay muchas tumbas de Osiris en Egipto, porque al encontrarse con cada parte, aquélla le construía un sepulcro. Pero otros dicen que no, que Isis hacía imágenes y las entregaba ciudad por ciudad, como si entregara su cuerpo, con el fin de que recibiera honores en el mayor número de ellas y, en el caso de que Tifón se impusiera a Horus, desistiera de buscar la tumba verdadera, al ser muchas las así consideradas y señaladas. La única parte de Osiris que Isis no encontró fue el miembro viril, pues fue arrojado enseguida al río y el lepidoto, el pagro y el oxirrinco lo devoraron, peces de los que especialmente abominan. Sin embargo Isis, en lugar del miembro viril, hizo una imitación de él y consagró el falo, en honor del cual todavía ahora los egipcios celebran una fiesta. 19. Más tarde, llegado Osiris del Hades junto a Horus, lo ejercitaba y lo entrenaba para la batalla; después le preguntó qué es lo que consideraba lo más hermoso; y al decirle él "vengar al padre y a la madre de uno por haber sido maltratados", le preguntó en segundo lugar cuál es el animal que consideraba más útil para quienes van al combate; y al responderle Horus "el caballo", se quedó sorprendido y preguntó por qué 
no más el león que el caballo; pues bien, Horus le respondió que el león era útil para quien necesitaba defensa, pero el caballo para dispersar y aniquilar al enemigo en la retirada. Osiris se alegró de oir esto, porque consideraba que Horus estaba lo suficientemente preparado. $\mathrm{Y}$ se dice que al ponerse muchos, sucesivamente, de parte de Horus, también se adhirió la concubina de Tifón, Tueris; una serpiente que perseguía a ésta fue hecha pedazos por los seguidores de Horus, y ahora, por esta razón, echando en el medio una cuerda, la cortan en trozos. Pues bien, el combate duró muchos días y venció Horus; a Tifón, aunque Isis lo recibió encadenado, ésta no lo hizo perecer, sino que lo soltó y lo dejó ir; pero Horus no soportó esto de buen temple, sino que echándole mano a su madre le arrancó de la cabeza la corona; Hermes, entonces, le cubrió la cabeza con un casco en forma de cabeza de vaca. Tifón incoó un proceso contra Horus por bastardía, pero, con la ayuda de Hermes, Horus fue declarado por los dioses hijo legítimo, y Tifón fue derrotado en otras dos batallas. De Osiris, unido a ella después de la muerte, Isis engendró a Harpócrates ${ }^{(10)}$, nacido prematuramente y con las extremidades inferiores debilitadas.

20. Éstos son más o menos los puntos importantes del mito, eliminados los más infames, cuales son el desmembramiento de Horus y la decapitación de Isis [...]

Set (en el texto de Plutarco, Tifón) es, pues, la encarnación del mal en el panteón egipcio: era pelirrojo, que era el color del desierto rojizo, odiaba y envidiaba a su hermano Osiris, y no dudó en asesinarle y arrebatarle el trono. Horus, hijo de Osiris, le derrotó y vengó así a su padre. Pero, originariamente, Set era simplemente el dios local de Ombos, la ciudad del oro en el Alto Egipto ya en tiempos predinásticos. Su carácter genuino era el de un dios guerrero, y como tal su figura fue reivindicada en varias ocasiones de la dilatada historia egipcia: la primera vez al final de la Dinastía II (c. 2890-2686 a. C.), como mínimo durante los reinados de Peribsen y de Jasejemuy; la segunda vez durante la dominación de los asiáticos hicsos, que lo identificaron con Baal (c. 1644-1537 a. C.), los cuales implantaron su culto en Ávaris, en el Delta oriental, hacia el 1730 a. C.; la tercera vez en época ramésida, cuando varios de los reyes de las Dinastías XIX y XX (c. 1305-1069 a. C.) fueron sacerdotes de Set y algunos incluso llevaron nombres como Setos y Setnajt. Con todo, el aumento progresivo de la popularidad de Osiris acarreó un mayor aborrecimiento por parte de los egipcios contra Set: de este modo, el dios de Ombos acabó siendo la personificación del desierto, de la esterilidad y del mal, y en definitiva de todos los aspectos negativos en oposición a 
Osiris que encarnaba los positivos. Las leyendas subsiguientes se encargarían de ir cargando más las tintas, atribuyendo a Set toda clase de aberraciones, incluida la homosexualidad.

Al mismo tiempo que se producían los primeros intentos de unificación mencionados más arriba, se producian como consecuencia de aquéllos otros intentos de secesión, justificados a su vez por otros sistemas cosmogónicos que situaban al correspondiente dios local de la ciudad secesionada como dios primordial; entre éstos, los más importantes fueron los casos de Tot en Hermópolis Parva y de Neit en Sais.

Finalmente, la unificación del Delta por la monarquía de Buto en las postrimerías del Período Predinástico, implicó la asunción de todos los anteriores símbolos monárquicos, así como la de los otros grandes dioses locales, que fueron reunidos en la llamada Pequeña Enéada de Heliópolis: Horus, Hathor, Tot, Anubis, Maat, etc. Una vez unificado Egipto hacia el 3100 a. C., las distintas escuelas teológicas locales adoptaron el sistema de Enéadas, que permitía dar una explicación coherente del cosmos, entendiendo como tal al mundo ordenado de dioses y hombres. Normalmente, lo único que cambiaba de un lugar a otro en dichas Enéadas era el dios primordial iniciador de la creación, el cual era en cada caso el dios local del nomo correspondiente.

En Heliópolis habían proseguido las elucubraciones teológicas, y a principios de la Dinastía III (c. 2686-2613 a. C.) se llegó a la división de la divinidad solar primordial en tres aspectos diferenciados, sin perder por ello su unidad: se trataba de Jepri, el Sol de la mañana; de Re, el Sol del mediodía; y de Atum, que quedaba como el Sol del atardecer. Al mismo tiempo, se llegaba a la adopción por la monarquía de la teología solar heliopolitana como propia, unificándose desde este momento el culto solar con el real y llegándose hasta a cambiar el ritual funerario real, con la adopción de la pirámide como lugar de enterramiento.

Paralelamente en Menfis, convertida en capital del estado, surgía una escuela teológica muy importante durante el Imperio Antiguo (c. 2686-2173 a. C.): de acuerdo con ella Ptah, el dios local, era el dios primordial. Hasta aquí, la cosa no tendría nada de original; la originalidad venía de la manera como Ptah procedió a la creación del mundo. Así, Ptah creó todo lo existente gracias al poder de su Verbo: el dios concebía las cosas en su pensamiento, pronunciaba su nombre y las cosas eran. Ptah creó también al hombre a su imagen, y concluida la creación quedó satisfecho de su obra. En las innovadoras concepciones menfitas se encuentra el origen de la moral y del humanismo egipcios. 


\section{El pecado: La «confesión negativa»}

El humanismo y la moral egipcios son, en definitiva, el resultado de la conjunción del panteísmo heliopolitano y del misticismo osiríaco, todo ello depurado por la escuela teológica de Menfis. Según estas concepciones, los hombres son iguales entre ellos y esencialmente iguales a los dioses, puesto que todos ellos podían alcanzar la eternidad. La diferencia era sólo de grado, puesto que los dioses eran más poderosos que los hombres. Los hombres, para alcanzar la eternidad, debían reunir una serie de requisitos, básicamente morales. A partir del Imperio Medio (c. 2040-1786 a. C.) - de hecho desde el Primer Período Intermedio (c. 2173-2040 a. C.) -, cada hombre debía comparecer después de muerto ante el tribunal de Osiris, donde se pesaban sus buenas y sus malas acciones y se juzgaba si era digno o no de la eternidad en los Campos Elisios, el paraíso de Osiris.

El capítulo 125 del Libro de los Muertos nos ha conservado la llamada "confesión negativa", o lista de pecados que el difunto declaraba no haber cometido ante el tribunal(11). He aquí la traducción de este interesante texto ${ }^{(12)}$ :

\section{Introducción}

(1) Texto para entrar en la Sala de la Doble Maat ${ }^{(13)}$, y para separar (a N. $)^{(14)}$ de los pecados cometidos y ver el rostro de los dioses: Homenaje a ti, dios grande, señor de la Doble Maat, yo he venido a ti, mi señor. Yo mismo he venido para ver tus glorias. Yo te conozco, y conozco el nombre de los 42 dioses que están contigo en la Sala de la Doble Maat, viviendo como castigadores de los pecadores, viviendo de su sangre en el día del cómputo de las disposiciones en presencia de Unnofre ${ }^{(15)}$. Verdaderamente "El de las dos hijas, El de las dos Meret ${ }^{(16)}$, Señor de Maat" es tu nombre. Verdaderamente yo he venido (6) a ti, yo te he traído Maat. Yo he acabado con el mal. Yo no he hecho daño a los hombres. Yo no he hecho daño a los animales. Yo no he dicho mentiras en el Lugar de la Verdad. Yo no he conocido la maldad. Yo no he actuado engañosamente. Yo no he hecho cada día y en todo trabajo sino lo que yo debía hacer. $\mathrm{Mi}$ nombre no ha llegado al barco del príncipe. Yo no he despreciado a Dios. Yo no he causado miseria. Yo no he causado aflicción. Yo no he hecho lo que es abominable (11) a Dios. Yo no he hecho maltratar al siervo por su señor. Yo no he causado pena. Yo no he provocado lágrimas. Yo no he matado. Yo no he ordenado matar. Yo no he hecho sufrir a los hombres. Yo no he robado las ofrendas de los templos. Yo no he reducido los alimentos de los dioses. Yo no he robado las 
ofrendas de los difuntos. Yo no he fornicado. Yo no he cometido actos impuros. (16) Yo no he aumentado ni he disminuido las medidas. Yo no he robado de la medida. Yo no he maltratado los campos. Yo no he añadido peso a la balanza. Yo no he quitado peso a la balanza. Yo no he quitado la leche de la boca del niño. Yo no he sacado el rebaño de sus pastos. Yo no he capturado pájaros de las reservas de los dioses. Yo no he cogido peces (con cebos) de sus propios cuerpos. Yo no he desviado el agua en su estación. Yo no he cortado el curso de un canal. Yo no he apagado la llama en su momento. Yo no he violado el tiempo de las ofrendas escogidas. Yo no he rechazado el ganado de propiedad divina. Yo no he obstaculizado a Dios en sus manifestaciones. (21) Yo soy puro (4 veces) [...]

Un poco más adelante viene la declaración de inocencia. Consta de una invocación a cada uno de los 42 jueces de los muertos, que forman el tribunal de Ultratumba. Tras el nombre de cada juez, el difunto declara no haber cometido un pecado:

Confesión ${ }^{(17)}$

(1) ¡Oh, El de largos pasos ${ }^{(18)}$, procedente de Heliópolis!, yo no he hecho el mal. ¡Oh, El que abraza la llama ${ }^{(19)}$, procedente de Jer-aha!, yo no he robado. ¡Oh, El Narigudo ${ }^{(20)}$, procedente de Hermópolis!, yo no he sido envidioso. ¡Oh, El Devorador de sombras, procedente de la Caverna!, yo no he matado hombres. ¡Oh, El Terrible de cara, procedente de Ro-stau!, yo no he defraudado con las ofrendas. (6) ¡Oh, Doble león ${ }^{(21)}$, procedente del cielo!, yo no he disminuido (las medidas). ¡Oh, El que sus dos ojos son de fuego ${ }^{(22)}$, procedente de Letópolis!, yo no he expoliado los bienes de un dios. ¡Oh, El Incandescente, procedente de Jetjet!, yo no he dicho mentiras. ¡Oh, El Rompedor de huesos, procedente de Heracleópolis!, yo no he sustraído comida. ¡Oh, El que activa la llama, procedente de Menfis!, yo no he afligido (a nadie). (11) ¡Oh, el Troglodita, procedente de Occidente!, yo no he cometido actos contranatura. ¡Oh, Aquel cuya cara está detrás de él, procedente de su caverna!, yo no he hecho llorar. ¡Oh, Bastis, procedente del lugar secreto!, yo no he sido insensible. ¡Oh, El de las piernas brillantes, procedente de la oscuridad!, yo no he transgredido. ¡Oh, El Bebedor de sangre, procedente del Lugar de ejecución!, yo no he actuado engañosamente. (16) ¡Oh, El Devorador de entrañas, procedente de la Morada de los Treinta!(23), yo no he devastado campos labrados. ¡Oh, Señor de Maat, procedente de Maaty!, yo no he espiado. ¡Oh, El Errante, procedente de Bubastis!, yo no he sido charlatán. ¡Oh, El Pálido(24), procedente de Heliópolis!, yo no me he irritado sin motivo. IOh, El Malvado, procedente de Andyeti!, yo no he cometido adulterio 
con la mujer de mi prójimo. (21) ¡Oh, Uamemty, procedente del Lugar del juicio!, yo no he cometido adulterio con la mujer de mi prójimo. ¡Oh, El que mira lo que le es presentado, que aparece en el templo de Min!, yo no he cometido actos impuros. ¡Oh, Jefe de los grandes, procedente de Imu!, yo no he causado temor. ¡Oh, El Destructor, procedente de Xois!, yo no he transgredido. ¡Oh, El que levanta la voz, procedente de Urit!, yo no me he inflamado. (26) ¡Oh, El Niño, procedente de Tebas!, yo no he sido sordo a las palabras de la verdad. ¡Oh, El Tenebroso, procedente de las tinieblas!, yo no he blasfemado. ¡Oh, El que aporta sus ofrendas, procedente de Sais!, yo no he actuado violentamente. ¡Oh, El Violento de palabras, procedente de Uniset!, yo no he sido violento. ¡Oh, El Señor de los rostros, procedente de Nedyefet!, yo no he juzgado precipitadamente. (31) ¡Oh, El que gobierna, procedente de Uten!, yo no he escuchado a escondidas. ¡Oh, Señor de los Dos Cuernos, procedente de Siut!, yo no he multiplicado las palabras de mis discursos. ¡Oh, Nefertem, procedente de Menfis!, yo no he sido pecador, yo no he hecho el mal. ¡Oh, Temsepu, procedente de Busiris!, yo no he insultado al rey. ¡Oh, El que actúa según su voluntad, procedente de Anteópolis!, yo no he ensuciado el agua. (36) ¡Oh, Ihy, procedente del Nun!(25), yo no he levantado la voz. ¡Oh, El que hace prosperar a los vivientes, procedente de Sais!, yo no he insultado a un dios. ¡Oh, Nehebkau ${ }^{(26)}$, procedente de su caverna!, yo no he actuado prepotentemente. ¡Oh, Nehebnefrut, procedente de su caverna!, yo no he reducido las ofrendas de los dioses. ¡Oh, El de la cabeza presti-giosa, procedente de su capilla!, yo no me he llevado la comida de los difuntos. (41) ¡Oh, El que trae su don ${ }^{(27)}$, procedente de Maaty!, yo no me he llevado la comida del niño, yo no he blasfemado contra el dios de mi ciudad. ¡Oh, El de los dientes blancos ${ }^{(28)}$, procedente del Fayum, yo no he matado el ganado divino!

Apéndice (de la edición de Naville)

(2) ¡Salud a vosotros, dioses aquí presentes! Yo os conozco. Yo conozco vuestros nombres. Yo no caeré bajo vuestros golpes, vosotros no haréis un mal informe de mí ante este dios al cual seguís, mi caso no llegará (ante él) por vuestra causa. Vosotros declarareis mis cosas justas ante (6) el Señor de Todo, porque yo he hecho cosas justas en Egipto. Yo no he blasfemado contra Dios, mi caso no ha llegado. ¡Salud a vosotros, dioses que estáis en vuestra sala de la Doble Maat, sin maldad en sus cuerpos, que viven en justicia en Heliópolis, que nutren sus corazones ante Horus que está en su Disco! Salvadme de $\mathrm{Baba}^{(29)}$, que vive de las entrañas de los grandes, en el día del gran juicio ante vosotros. Yo he venido a vosotros, yo no he pecado, yo no he delinquido, yo no he hecho mal, yo no tengo acusador, yo no he 
hecho nada contra nadie. Yo vivo de la justicia, yo alimento mi corazón de justicia. Yo he hecho lo que los hombres ordenan, lo que alegra a los dioses. Yo he satisfecho a Dios con lo que él ama: (11) yo he dado pan al hambriento, agua al sediento, vestidos al desnudo y una barca a quien no tenía. Yo he hecho el servicio de ofrendas divinas a los dioses y el de las ofrendas funerarias para los difuntos. ¡Salvadme, protegedme, no me acuséis ante el gran dios! [...]

El capítulo 125 del Libro de los Muertos contiene, pues, un auténtico catálogo de pecados, que recuerda poderosamente los Diez Mandamientos bíblicos en su exposición negativa, y que el difunto declaraba no haber cometido. Si superaba la prueba, era declarado "justo de voz", es decir, que no había mentido al hacer su declaración.

En la religión egipcia el mal no emana nunca de la divinidad, sino de la libertad de los hombres. Así, por ejemplo, en los Textos de los Sarcófagos del Imperio Medio, la divinidad creadora declara:

Yo hice a todos los hombres iguales a su prójimo. Yo no les ordené hacer el mal, sino que fueron sus corazones quienes transgredieron mi palabra(30).

La libertad debe, en principio, ser usada para hacer el bien, y en ello insisten tanto las enseñanzas del Imperio Antiguo - su más brillante representante son las Enseñanzas de Ptahhotep, donde se exponen por primera vez los principios universales de la moral natural - como las autobiografías de esta misma época. Veamos, por ejemplo, un pasaje de la de Neferseshemre:

He dicho la verdad, he ejecutado la justicia, he dicho el bien, he repetido el bien, he alcanzado la perfección, ya que deseaba que el bien estuviese entre los hombres. He juzgado a dos litigantes de manera que ambos quedasen satisfechos. He salvado al desgraciado de la mano del más poderoso que él, cuando he tenido poder para hacerlo. He dado pan al hambriento y ropa al que estaba desnudo; he hecho subir a los demás en mi barca. He excavado una tumba para quien no tenía hijo. He hecho una barca para quien no tenía. He venerado a mi padre, he sido cariñoso con mi madre y he educado a sus hijos ${ }^{(31)}$.

\section{El castigo}

Pero el hombre se sabe pecador, y sabe que el pecado acarrea el castigo, lo cual se expone ya claramente desde el Primer Período 
Intermedio, en las Enseñanzas para el rey Merikare; de esta manera, las sospechas de culpabilidad recaían sobre quienes morían violenta o accidentalmente. En cambio, en la religión egipcia no existe el concepto de pecado original.

De todos modos, para superar el juicio ante Osiris sólo los criterios morales eran válidos. Normalmente, el castigo para quienes no superaban la prueba no era otro que la destrucción y la pérdida de la inmortalidad; de ahí la gravedad de la damnatio memoriae para los egipcios, que ponía seriamente en peligro la supervivencia en el Más Allá de las víctimas de este castigo. Sin embargo, no había infierno.

Tenemos, con todo, una excepción; se trata de los Prodigios mágicos de Siosiris, texto demótico de hacia el siglo VI a. C. En esta historia Setne, hijo de Rameses II, tiene un hijo llamado Siosiris, que es un poderoso mago y en realidad la reencarnación de Horus. Veamos ahora el fragmento que nos interesa ${ }^{(32)}$ :

Y tras esto sucedió un día que Setne estaba lavándose para la fiesta en la terraza de sus aposentos, y que el pequeño Siosiris se lavaba también ante él para acompañarlo a la fiesta. En este momento Setne oyó unas voces muy fuertes que entonaban lamentos: se asomó para mirar desde la terraza de sus aposentos y divisó el cortejo de un rico al que conducían para enterrarlo en la montaña, con grandes honores fúnebres y cantos lúgubres. Miró por segunda vez a sus pies y divisó el duelo de un hombre pobre, a quien sacaban de Menfis arrollado en una estera, solo y sin nadie que formase su cortejo.

Setne dijo: "¡Por vida de Osiris, el señor del Amentit!(33), jojalá se me haga en el Amentit como a esos ricos que reciben grandes lamentaciones, y no como a esos pobres que son llevados a la montaña sin pompa ni honores!"

Siosiris, su hijito, le dijo: “iOjalá se te haga en el Amentit lo que se hace a ese pobre hombre en el Amentit, y no se te haga en el Amentit lo que se hace a este rico en el Amentit!"

Cuando Setne oyó las palabras que Siosiris, su hijito, le había dicho, su corazón se afligió extraordinariamente, y le dijo:

"¿Acaso lo que oigo es la voz de un hijo que ama a su padre?"

Siosiris, su hijito, le dijo:

"Si ello te place, te mostraré a cada cual en su lugar, al pobre a quien no lloran y al rico a quien lamentan.»

Setne preguntó:

"¿Y cómo podrás hacer esto, Siosiris, hijo mío?»

Entonces el pequeño Siosiris se puso a recitar textos desconocidos. Tomó a su padre Setne de la mano y le condujo a un lugar que él no 
conocía en la montaña de Menfis. Allí había siete grandes salas, y en ellas se apiñaban hombres de todas las condiciones. Atravesaron las tres primeras salas, sin que nadie les detuviese. Al entrar en la cuarta sala, Setne pudo ver gentes que corrían y se agitaban, en tanto unos asnos comían sobre sus espaldas ${ }^{(34)}$; otros tenían su comida, agua y pan, suspendida sobre ellos y tendían sus brazos para alcanzarla, mientras que otros cavaban agujeros bajo sus pies para impedírselo.

Cuando llegaron a la quinta sala, Setne descubrió a difuntos venerables, colocados en sitios distinguidos, mientras que los que habian sido acusados de haber cometido crímenes permanecían de pie ante la puerta, suplicantes, y el espigón del quicio de la puerta de esta quinta sala estaba clavado en el ojo derecho de un hombre que imploraba a gritos piedad.

Cuando alcanzaron la sexta sala, Setne vio a los dioses que juzgan a los difuntos en el Amentit. Cada uno ocupaba su sitio correspondiente, mientras los ujieres del Amentit citaban las causas una por una. En la sexta sala, Setne contempló la figura de Osiris, el dios grande, sentado en su trono de oro fino, coronado con la diadema de las dos plumas; a Anubis, el dios grande, a su izquierda; a Tot, el dios grande, a su derecha; y a los dioses del tribunal del Amentit a su izquierda y a su derecha, con la balanza en medio y frente a ellos en la que pesaban las malas y las buenas acciones, en tanto Tot, el dios grande, cumplia las funciones de escriba y Anubis les dirigía la palabra. Aquél cuyas malas acciones sean juzgadas más numerosas que sus méritos, será entregado a Amait, la perra del señor del Amentit, se destruirá su alma y su cuerpo y no se le permitirá respirar nunca más. Aquel cuyos méritos sean juzgados más numerosos que sus malas acciones, es conducido entre los dioses del tribunal del señor del Amentit, y su alma va al cielo entre los difuntos venerables. Aquel cuyos méritos sean juzgados equivalentes a sus malas acciones, es colocado entre los difuntos provistos de amuletos servidores de Sócares-Osiris.

Entonces, Setne vio a un personaje distinguido, revestido de túnicas de lino fino, que estaba colocado cerca de Osiris, en un lugar honorable. Mientras Setne se maravillaba por todo lo que veía en el Amentit, Siosiris se puso delante de él diciendo:

«Padre mío Setne, ¿ves a este eminente personaje vestido de lino fino y que está cerca del sitio donde se encuentra Osiris? Pues es aquel pobre hombre que viste que sacaban de Menfis, sin que nadie le acompañara, y que iba envuelto en una estera. Le llevaron al Hades, y pesaron sus malas acciones contra los méritos que tuvo mientras estaba sobre la tierra, y se encontraron más numerosos sus méritos que sus malas acciones. Dado que el tiempo de vida que Tot inscribió en su cuenta no correspondía a una cantidad de dicha suficiente mientras estaba sobre la tierra, se ordenó ante Osiris que se trans- 
firiera el ajuar funerario de aquel rico que viste sacar de Menfis con grandes honores a este pobre hombre que tienes ahí, y luego se mandó que se le colocara entre los difuntos venerables fieles de Sócares-Osiris, cerca del sitio donde está Osiris. El rico que viste le llevaron al Hades, pesaron sus malas acciones contra sus méritos, se le encontraron numerosas malas acciones, más que los méritos que tuvo sobre la tierra, y se ordenó que se le retribuyera en el Amentit, y es a él a quien has visto, con el espigón del quicio de la puerta del Amentit clavado en su ojo derecho y girando sobre ese ojo, tanto si se abre como si se cierra, mientras su boca profiere grandes alaridos. Por la vida de Osiris, el dios grande, señor del Amentit, si te he dicho sobre la tierra: " $i$ Que se te haga como se ha hecho con este pobre hombre, pero que no se te haga como se ha hecho con este rico!", es porque yo sabía lo que iba a ocurrirle a éste.

Este texto recuerda poderosamente la parábola evangélica del rico Epulón y el pobre Lázaro. Pero también tiene otros ecos, tanto cristianos como de la mitología greco-romana. Sin embargo, su fecha avanzada no impide pensar en que el pensamiento funerario egipcio haya podido recibir ya influencias externas.

Otra cuestión es la del castigo de los criminales por la justicia real, pero esto nos llevaría ya definitivamente demasiado lejos del objetivo de nuestra exposición.

\section{Notas}

(1) Para una visión reciente de la religión y la mitología egipcias puede verse JESÚS LÓPEZ, JOAQUÍN SANMARTÍN, Mitología y Religión del Oriente Antiguo, I. Egipto Mesopotamia, "Colección: Estudios Orientales", 7, Sabadell, 1993.

(2) Para las implicaciones de la política, la mitología y la teología en Egipto ya desde tiempos predinásticos puede consultarse JOSEP PADRÓ, Historia del Egipto Faraónico, "Manuales/Historia y Geografía", 9, Madrid (7." edición), 2008.

(3) El texto griego, con traducción inglesa, puede consultarse en: PLUTARCH, Moralia, V (ed. Frank Cole Babbitt), "The Loeb Classical Library", 306, Londres, 1936; el De Iside et Osiride se encuentra en las pp. 1-191. Para una traducción reciente al castellano, ver: PLUTARCO, Obras Morales y de Costumbres (Moralia), VI (tr. Francisca Pordomingo Pardo y José Antonio Fernández Delgado), “Biblioteca Clásica Gredos», 213, Madrid, 1995, pp. 7-207. Nosotros hemos utilizado aquí esta traducción, debida a F. Pordomingo.

(4) Se trata del dios Atum.

(5) Se trata, respectivamente, de la diosa Nut y del dios Gueb.

(6) El dios Tot.

(7) El dios Amón. 
(8) El dios Horus el Grande o Horus el Venerable.

(9) El dios Set.

(10) Harpócrates significa, en egipcio, Horus el Niño.

(11) Los ejemplares conservados del Libro de los Muertos son innumerables y se distribuyen por colecciones y museos de todo el mundo. La edición considerada canónica es la de ÉDOUARD NAVILLE, Das aegyptische Todtenbuch des XVIII. bis XX. Dynastie, aus verschiedenen Urkunden zusammengestellt, Berlín, 1886, 3 vols., que ha sido reeditada recientemente. La edición más divulgada en la actualidad es la de E. A. WALLIS BUDGE, The Book of the Dead. The Papyrus of Ani in the British Museum, Londres, 1895, tambien reeditada no hace mucho en una edición económica y con una amplia tirada. Traducciones, además de la de Budge en la obra citada, hay que mencionar las de BORIS DE RACHEWILTZ, // Libro dei Morti degli antichi Egiziani, Milán, 1958, y de PAUL BARGUET, Le Livre des Morts des Anciens Égyptiens, "Litteratures Anciennes du Proche-Orient", 1, París, 1967. Es necesario resaltar que en la actualidad no existe ninguna traducción directa del egipcio a la lengua castellana, con el fin de poner sobre aviso al lector no especializado.

(12) Es preciso señalar que en egiptología la simple transliteración fonética sin el apoyo del texto jeroglífico es de escasa utilidad, ya que es precisamente la presencia de los signos no fonéticos - ideogramas y determinativos - la que confiere el significado exacto de las palabras. Es por este motivo que en egiptología, y contrariamente al uso de otras disciplinas filológicas próximo-orientales, es más importante dar la versión jeroglífica de un texto dado que su transliteración fonética, y en los diccionarios y gramáticas no puede prescindirse jamás de la forma jeroglífica de las palabras. Por todo ello, hemos optado por dar aquí exclusivamente la traducción del capítulo CXXV del Libro de los Muertos. El texto jeroglífico que hemos usado es el de BUDGE, The Book of the Dead, cit., pp. 193-198, para la Introducción, que sigue la edición de NAVILLE, Todtenbuch, cit., vol. I; pp. 198-203, para la Confesión, tomada del Papiro de Ani; y pp. 203-205 para el Final de la Confesión, que sigue nuevamente la edición de NAVILLE, loc. cit.

(13) Maat es la diosa de la verdad, de la justicia, del orden cósmico en suma. La Doble Maat es, probablemente, una alusión a Isis y Neftis.

(14) N. es el nombre del propietario de cada ejemplar del Libro de los Muertos.

(15) Unnofre es Osiris, "el Permanentemente Perfecto". Se trata del nombre actual Onofre.

(16) Las dos hijas y las dos Meret son Isis y Neftis.

(17) Las variantes textuales de la confesión son muy numerosas. No obstante, por lo general se limitan a la no concordancia, de un manuscrito a otro, del nombre de cada juez con su pecado correspondiente. Evidentemente, los copistas se equivocaban con frecuencia y lo resolvian cambiando jueces y pecados, sin dar más importancia al asunto.

(18) $\mathrm{Re}$, que recorre el cielo a grandes pasos.

(19) Probablemente Atum.

(20) Tot, en alusión al largo pico de su animal sagrado, el ibis.

(21) Probablemente Atum.

(22) Haroeris, Horus el Grande o el Venerable.

(23) Es decir, el tribunal.

(24) Epíteto probable del Sol. 
(25) Las aguas primordiales.

(26) "El que reune los kas (en él)», nombre de una divinidad serpiente.

(27) Divinidad serpiente; su don sería su veneno.

(28) El dios cocodrilo Sobek.

(29) Genio maligno, de forma de perro.

(30) Pasaje citado por SIEGFRIED MORENZ, La Religion Égyptienne, París, 1962, pp. 85 y 87-88; utilizamos la versión francesa de esta obra.

(31) Texto citado en JOSEP PADRÓ, Historia del Egipto Faraónico, cit., p. 128, tomado de la traducción de ALESSANDRO ROCCATI, La Littérature historique sous l'Ancien Empire Égyptien, "Littératures Anciennes du Proche-Orient», 11, París, 1982, pp. 144-145.

(32) Traducción de G. MASPERO, Les Contes Populaires de l'Égypte Ancienne, París, 1911 , pp. 133-137.

(33) El Occidente, lugar al que van los difuntos.

(34) Los asnos que comen por detrás no son sino las mujeres que en vida se aprovecharon de ellos y les llevaron a la ruina. 